SPECIAL REPORT

\title{
Wilderness Injury, Illness, and Evacuation: National Outdoor Leadership School's Incident Profiles, 1999-2002
}

\author{
Drew Leemon; Tod Schimelpfenig \\ From the National Outdoor Leadership School, Lander, WY.
}

\begin{abstract}
Objective.-This paper describes field injury, illness, near miss, and evacuation profiles of the National Outdoor Leadership School (NOLS).

Methods.-The NOLS incident database is used to record injuries, illnesses, near-miss incidents (close calls), evacuations, and nonmedical incidents. The database has been used continually since 1984.

Results.-During the period September 1, 1998, through August 31, 2002, there were 630937 program days on which 1940 incidents were reported involving 1679 students and 233 staff. Athletic injuries account for $50 \%$ of all injuries, and soft-tissue injuries account for $30 \%$. Athletic injuries are most often sprains and strains of knees (35\%), ankles (30\%), and backs (13\%). Falls and slips around camp or while hiking are the leading contributing factors. The most common illnesses are gastrointestinal symptoms such as nausea, vomiting, and diarrhea (26.4\%) and all flu-like illness, including flu symptoms and respiratory symptoms (16.6\%). Rock fall was the leading near-miss incident. Two hundred fifty-seven $(53 \%)$ medical evacuees received treatment and were able to rejoin and finish their course. There was one fatality from 1999 to 2002. The fatality rate for this period is 0.002 per 1000 program days.

Conclusions. - The number of injuries and, specifically, the number of athletic injuries have declined. The number and rate of near-miss incidents increased as a result of better reporting; the rate of nonmedical incidents held steady. Motivation continues to be our leading category of nonmedical incident. Efforts at collecting incident data provide a useful measurement from which we can gauge our risk-management performance.
\end{abstract}

Key words: wilderness, wilderness medicine, injury, illness, evacuation

\section{Introduction}

The National Outdoor Leadership School (NOLS), founded in 1965, is headquartered in Lander, WY, and operates schools in Wyoming, Alaska, Arizona, Washington, Idaho, Mexico, Chile, and the Yukon Territory, Canada. NOLS also conducts courses in the Garhwal Himalaya of India, New Zealand, and northwestern Australia. Approximately 3000 students enroll annually, participating in more than 150000 field days of multi-week wilderness expeditions. Founded to train leaders for wilderness programs, NOLS develops judgment, leadership, and wilderness skills in its participants.

Corresponding author: Drew Leemon, National Outdoor Leadership School, 284 Lincoln St, Lander, WY 82520 (e-mail: drew_leemon@ nols.edu).
An important aspect of the risk-management strategy of NOLS is to collect information on injuries, illnesses, and other risk-management incidents. This paper will examine the type of incidents we experience by presenting injury, illness, near miss, and evacuation profiles. NOLS firmly believes that an organization that understands its risk-management history is better able to identify if and when changes in risk-management methods are necessary. This type of information can also be useful for our students and their families to better understand the types of risks inherent to participation in NOLS courses. The data presented in this paper will provide important perspective to risk management at NOLS.

The term incident is used at NOLS when referring to events related to the health, safety, and welfare of NOLS students and staff. Incident is defined as "an occurrence 
Table 1. National Outdoor Leadership School (NOLS) field safety data summary 1984-2002*

\begin{tabular}{|c|c|c|c|c|c|c|c|c|}
\hline & \multicolumn{2}{|c|}{$\begin{array}{c}\text { Fiscal years } \\
\text { 1984-1989 } \\
\text { (358210 } \\
\text { program days) }\end{array}$} & \multicolumn{2}{|c|}{$\begin{array}{c}\text { Fiscal years } \\
\text { 1990-1994 } \\
\text { (584 } 329 \\
\text { program days) }\end{array}$} & \multicolumn{2}{|c|}{$\begin{array}{c}\text { Fiscal years } \\
\text { 1995-1998 } \\
(551745 \\
\text { program days) }\end{array}$} & \multicolumn{2}{|c|}{$\begin{array}{c}\text { Fiscal years } \\
\text { 1999-2002 } \\
\text { (630937 } \\
\text { program days) }\end{array}$} \\
\hline & $\begin{array}{c}\text { No. of } \\
\text { incidents }\end{array}$ & Rate $\dagger$ & $\begin{array}{c}\text { No. of } \\
\text { incidents }\end{array}$ & Rate $\dagger$ & $\begin{array}{c}\text { No. of } \\
\text { incidents }\end{array}$ & Rate $\dagger$ & $\begin{array}{c}\text { No. of } \\
\text { incidents }\end{array}$ & Rate $\dagger$ \\
\hline All injury & 839 & 2.30 & 1041 & 1.78 & 710 & 1.29 & 678 & 1.07 \\
\hline Athletic injury & 443 & 1.24 & 519 & 0.89 & 365 & 0.66 & 342 & 0.54 \\
\hline All illness & 529 & 1.50 & 783 & 1.34 & 506 & 0.92 & 549 & 0.87 \\
\hline Gastrointestinal symptoms & 183 & 0.51 & 341 & 0.58 & 111 & 0.20 & 137 & 0.22 \\
\hline Flu-like illness & 163 & 0.46 & 219 & 0.37 & 131 & 0.24 & 105 & 0.17 \\
\hline Near miss & 237 & 0.66 & 259 & 0.44 & 307 & 0.56 & 418 & 0.66 \\
\hline Nonmedical incident & 122 & 0.34 & 198 & 0.34 & 284 & 0.51 & 282 & 0.45 \\
\hline Injury evacuation & 348 & 1.00 & 417 & 0.71 & 346 & 0.63 & 338 & 0.54 \\
\hline Illness evacuation & 181 & 0.50 & 258 & 0.44 & 210 & 0.38 & 203 & 0.32 \\
\hline Total medical evacuation & 529 & 1.47 & 674 & 1.15 & 556 & 1.01 & 541 & 0.86 \\
\hline Total evacuation & 634 & 1.77 & 846 & 1.45 & 748 & 1.36 & 755 & 1.20 \\
\hline
\end{tabular}

*Data represent participation on NOLS courses regardless of activity and includes students and staff.

$\dagger$ Rates are per 1000 program days.

tNot all nonmedical incidents are evacuations.

of an action or situation that is a separate unit of experience" 1 and allows us to refer to events in a more factual way. Incident is a nonjudgmental way to refer to events that may be accidental, intentional, a force of nature, or an outcome of the inherent risks of participating in a NOLS course. Significant incidents are analyzed in more depth when necessary.

NOLS has collected incident data since 1978. The data in this paper are taken from an incident database dating back to 1984 . We collected incident data on injuries, illnesses, near-miss incidents (close calls), evacuations, and nonmedical incidents. Specific criteria for what constitutes a reportable incident have been developed and meet 1 or more of the following instances:

- An injury or illness that requires more than simple first aid.

- Needs follow-up care or the use of prescription medications.

- Interferes with active participation for 12 hours beginning the next day (lost-day case).

- The person is evacuated.

- The incident is a near miss (close call).

Field instructors report incidents by completing special report forms. School program supervisors review reported incidents, and the information is then passed to the risk-management director for further review, analysis, and distribution to interested audiences (eg, the
NOLS executive management team, NOLS Risk Management Committee, NOLS Board of Trustees, field instructors, and students and their families). The NOLS incident database is kept on Filemaker Pro software and is maintained by the risk-management director.

For this paper, we examined incident data for the 4year period from September 1, 1998, through August 31, 2002, which corresponds to the NOLS fiscal years 1999-02. During this period, a total of 1940 incidents were reported. Incidents involving students totaled 1679 (746 women and 868 men). Gender was not reported in 65 incidents because the incident involved more than 1 person. Staff was involved in 233 incidents (81 women and 152 men). Twenty-eight incidents directly involved both students and staff. There were 12322 students and 6051 instructor positions (filled by 845 individual instructors) for the study period during a total of 630937 program days ( 1 program day equals 1 person on a course for 1 day).

\section{Historical data}

Table 1 presents the total NOLS historical incident data from 1984 to 2002 for both students and staff. A subset of these data was published in $1989 .^{2}$ Each grouping of data is for a different number of years; therefore, direct comparison of the number of incidents would be misleading. The rates provide a more useful comparison. 
Table 2a. Student injury profile: Injury type

\begin{tabular}{lcc}
\hline \multicolumn{1}{c}{ Injury type } & $\begin{array}{c}\text { No. of } \\
\text { injuries }\end{array}$ & $\begin{array}{c}\text { \% all } \\
\text { injuries }\end{array}$ \\
\hline Athletic & 301 & 49.9 \\
Soft tissue, all & 186 & 30.8 \\
$\quad$ Burns & 30 & 5.0 \\
Blisters & 22 & 3.6 \\
Wound infections & 18 & 3.0 \\
$\quad$ Stings & 13 & 2.2 \\
Head without loss of consciousness & 23 & 3.8 \\
Fracture & 22 & 3.6 \\
Dislocation & 20 & 3.3 \\
Dental & 19 & 3.2 \\
Nonfreezing cold injury & 14 & 2.3 \\
Frostbite & 8 & 1.3 \\
Other & 6 & 1.0 \\
Snow blindness & 2 & 0.3 \\
Head with loss of consciousness & 2 & 0.3 \\
$\quad$ Total & 603 & 100 \\
\hline
\end{tabular}

Rates per 1000 program days are used to provide fair comparison over time as enrollment changes and between NOLS schools of different sizes. Injury and illness evacuations are subsets of medical evacuations. Evacuations are a subset of the overall incident set.

Some attempts have been made to compare NOLS data with similar data from other programs, but signifi-

Table 2b. Student injury profile: Contributing factor

\begin{tabular}{lcc}
\hline \multicolumn{1}{c}{ Contributing factor } & $\begin{array}{c}\text { No. of } \\
\text { injuries }\end{array}$ & $\begin{array}{c}\text { \% all } \\
\text { injuries }\end{array}$ \\
\hline Fall/slip & 171 & 28.2 \\
Overuse & 161 & 26.7 \\
Previous history & 40 & 6.6 \\
Animal/insect/plant & 35 & 5.8 \\
Stove fire/spilled hot water & 24 & 4.0 \\
Unknown & 20 & 3.3 \\
Hygiene & 18 & 3.0 \\
Weather & 16 & 2.7 \\
Technique & 15 & 2.5 \\
Inexperience & 13 & 2.2 \\
Dental & 11 & 1.8 \\
Carelessness & 10 & 1.7 \\
Failed to follow instructions & 9 & 1.5 \\
Equipment & 8 & 1.3 \\
Exceeded ability & 7 & 1.2 \\
Other & 7 & 1.2 \\
18 factors at $<1 \%$ each & 38 & 6.3 \\
Total & 603 & 100 \\
& & \\
\hline
\end{tabular}

Table 2c. Student injury profile: Activity at time of injury

\begin{tabular}{lcc}
\hline \multicolumn{1}{c}{ Activity } & $\begin{array}{c}\text { No. of } \\
\text { injuries }\end{array}$ & $\begin{array}{c}\text { \% all } \\
\text { injuries }\end{array}$ \\
\hline Hiking with pack & 278 & 46.1 \\
In camp & 103 & 17.1 \\
Hiking without pack & 33 & 5.5 \\
Mountaineering & 29 & 4.8 \\
River boating, all & 25 & 4.1 \\
River canoe & 11 & 1.8 \\
River kayak & 13 & 2.2 \\
River raft & 1 & 0.2 \\
Cooking & 23 & 3.8 \\
Sea kayaking & 20 & 3.3 \\
Skiing & 16 & 2.7 \\
Swimming/wading & 14 & 2.3 \\
Rock climbing & 12 & 2.0 \\
Bouldering & 7 & 1.2 \\
Sailing & 6 & 1.0 \\
12 activities at $<1 \%$ each & 37 & 6.1 \\
Total & 603 & 100 \\
& & \\
\hline
\end{tabular}

cant differences in organizational mission, thresholds for reportable incidents, and other factors make this type of comparison inappropriate. The true value of these data to NOLS is that we are able to track trends over time, identify problem areas, implement incident mitigation strategies, and then monitor their efficacy. For example, we deemed the incidence of gastrointestinal and flu-like illness to be high in the 1980s and early 1990s. We instigated some changes aimed at improving hygiene in our practices and have had continual focus on this ever since. As a result, the rate of these illnesses has steadily declined. The following profiles of injuries, illnesses, near misses, and evacuations will provide more detailed examination of the data.

\section{Injury profile}

The injury rate for 1999-2002 as shown in Table 1 is lower than all previous periods and is $17 \%$ lower than the period from 1995 to 1998 . Athletic injuries are down $18 \%$, which accounts for much of this positive trend.

Table $2 \mathrm{a}, \mathrm{b}$, and c is our injury profile for 1999-2002, showing 3 categories of information: the injury type, the contributing factor of the injury, and the activity at the time of injury.

\section{INJURY TYPE}

Athletic and soft-tissue injuries account for over $80 \%$ of all injuries. Athletic injuries, though declining over time 
Table 2d. Injury occurrence as related to day of course

\begin{tabular}{cccccc}
\hline & \multicolumn{2}{c}{ All semesters } & & \multicolumn{2}{c}{ All other courses } \\
\cline { 2 - 3 } \cline { 5 - 6 } $\begin{array}{c}\text { Day of } \\
\text { course }\end{array}$ & $\begin{array}{c}\text { No. of } \\
\text { injuries }\end{array}$ & $\begin{array}{c}\text { \% all } \\
\text { injuries }\end{array}$ & & $\begin{array}{c}\text { No. of } \\
\text { injuries }\end{array}$ & $\begin{array}{c}\text { \% all } \\
\text { injuries }\end{array}$ \\
\hline $1-10$ & 57 & 20.2 & & 170 & 53 \\
$11-20$ & 49 & 17.4 & & 104 & 32 \\
$21-30$ & 32 & 11.3 & & 41 & 13 \\
$31-40$ & 31 & 10.9 & & 6 & 2 \\
$41-50$ & 35 & 12.4 & & $\ldots$ & $\ldots$ \\
$51-60$ & 34 & 12.1 & & $\ldots$ & $\ldots$ \\
$61-70$ & 20 & 7.1 & & $\ldots$ & $\ldots$ \\
$71-80$ & 20 & 7.1 & $\ldots$ & $\ldots$ \\
$>80$ & 4 & 1.4 & $\ldots$ & $\ldots$ \\
Total & 282 & 99.9 & 321 & 100.0 \\
\hline
\end{tabular}

(see Table 1), continue to be the most common and account for $50 \%$ of all injuries. Athletic injuries are most often sprains and strains of knees $(35 \%)$, ankles $(30 \%)$, and backs $(13 \%)$. We have been addressing this injury type by providing fitness information to students as part of their enrollment information, striving to reduce pack weights, carefully planning course routes, emphasizing warming-up and stretching before hiking and strenuous activities, and deliberately teaching students how to hike on rugged and uneven terrain. We are pleased with the decline in athletic injury rate and will continue our efforts. Significant further reductions in this rate could likely happen only by reducing the physical challenge of our courses, which are strenuous. Eliminating the physical challenge is impossible in wilderness and would fundamentally alter the activity, the outcome, and the NOLS mission.

\section{CONTRIBUTING FACTOR}

There is usually more than 1 factor that contributes to an incident. Table $2 \mathrm{~b}$ lists the most prominent contributing factor for each injury, with falls and slips being the leading factor. These are generally simple falls that occur around camp or while hiking. Less than $10 \%$ of all falls and slips involve more significant mechanisms such as falls down snow slopes, into crevasses, or from a height. The cause overuse is directly related to athletic injuries and is a factor of the repetitive movements or strenuous nature involved in NOLS activities.

\section{ACTIVITY}

Table 2c shows that hiking and time in camp are by far the most common activities when one is injured. These are also the most common activities at NOLS.
Table 3a. Student illness profile: Illness type

\begin{tabular}{lcc}
\hline \multicolumn{1}{c}{ Illness type } & $\begin{array}{c}\text { No. of } \\
\text { illnesses }\end{array}$ & $\begin{array}{c}\text { \% all } \\
\text { illnesses }\end{array}$ \\
\hline Nausea/vomiting/diarrhea & 124 & 26.4 \\
Respiratory infection & & \\
$\quad$ (flu-like and non-flu-like) & 78 & 16.6 \\
Illness infection & 52 & 11.1 \\
Gender related* & 36 & 7.7 \\
Abdominal pain & 32 & 6.8 \\
Other & 30 & 6.4 \\
Urinary tract infection & 29 & 6.2 \\
Acute mountain sickness & 21 & 4.5 \\
Allergy & 14 & 3.0 \\
Asthma & 9 & 1.9 \\
Dehydration & 9 & 1.9 \\
Tick fever & 7 & 1.5 \\
Hypothermia & 7 & 1.5 \\
Cardiac & 6 & 1.3 \\
5 illnesses at $<1 \%$ each & 15 & 3.2 \\
Total & 469 & 100 \\
& & \\
\hline
\end{tabular}

*Dysmenorrhea, mittelschmerz, vaginitis, ectopic pregnancy, testicular torsion, epididymitis.

We track the day of the course an incident occurs. Table $2 \mathrm{~d}$ lists the number of injuries that occurred and at what point during the course. We have separated semester courses (65-95 days long) from all other courses (9-35 days long, the majority of these are for 4 weeks). The majority of injuries ( $20 \%$ for semesters and $53 \%$ for all other courses) occur during the first 10 days. Of the 227 total injuries that occur in the first 10 days of a course, $137(60 \%)$ were athletic.

The first 10 days may be the most physically demanding part of a course. Students have to adjust to the demands of carrying heavy backpacks, possibly for the first time in their lives, and they have to adjust to the living conditions and environment. These data again point to the importance of physical conditioning before the course, careful and conservative route planning for the beginning of a course, and the need for an appropriate progression of physical challenge.

\section{Illness profile}

The rate for all illnesses (students and staff combined) declined slightly in the 1999-2002 data (see Table 1) from the previous period. Table 3 a lists illness type; Table $3 \mathrm{~b}$ lists the contributing factor of illnesses. The most common illnesses among students at NOLS are gastrointestinal symptoms such as nausea, vomiting, and diarrhea $(26.4 \%)$ and all respiratory infections, including 
Table 3b. Student illness profile: Contributing factor

\begin{tabular}{lcc}
\hline \multicolumn{1}{c}{ Contributing factor } & $\begin{array}{c}\text { No. of } \\
\text { illnesses }\end{array}$ & $\begin{array}{c}\text { \% all } \\
\text { illnesses }\end{array}$ \\
\hline Unknown & 281 & 59.9 \\
Previous history & 40 & 8.5 \\
Hygiene & 33 & 7.0 \\
Altitude & 24 & 5.1 \\
Animal/insect/plant & 22 & 4.7 \\
Other & 18 & 3.8 \\
Food or water & 16 & 3.4 \\
Fatigue & 12 & 2.6 \\
Failed to follow directions & 6 & 1.3 \\
Asthma & 6 & 1.3 \\
Weather & 4 & 0.9 \\
Medications/drugs & 3 & 0.6 \\
Dental & 3 & 0.6 \\
Inexperience & 1 & 0.2 \\
$\quad$ Total & 469 & 100 \\
& & \\
\hline
\end{tabular}

flu symptoms and non-flu-like respiratory symptoms $(16.6 \%)$. The distinction between flu and non-flu-like respiratory symptoms depends upon diagnosis by a health care professional. The rates of gastrointestinal and flu-like illness have decreased since the 1980s and seem to have leveled off for the period of 1995-2002 (Table 1). We believe the incidence of these illnesses is influenced by hygiene, and the long-term decline in the rate reflects our concerted efforts to improve hygiene. These efforts include emphasizing hand washing and camp hygiene, educating students and instructors on food-borne illness, expecting all wilderness drinking water to be disinfected, and repeatedly restating our expectations in these areas throughout the course.

The category of illness infections includes skin infections not associated with wounds, such as dermatitis and staphylococcus infections, along with ear, eye, or dental infections. The illness type other includes uncommon illnesses or vague and unspecified symptoms. Examples include migraine headaches, vertigo, or lingering symptoms from conditions previous to NOLS such as surgical or dental procedures. The most common cause of illness is termed unknown. Pinpointing the cause of many illnesses we encounter is difficult because they develop over time.

\section{Near-miss profile}

A near miss, or close call, is a dangerous situation where safety was compromised but did not result in injury. It is an unplanned and unforeseen event where the danger was missed by a small margin. In addition to the broad definition, some specific near-miss thresholds have been defined by NOLS to clarify when an incident is reportable.

\section{Climbing/mountaineering}

- Any leader fall, excluding anticipated or routine leader falls on sport routes, or slips of a few feet or less.

- An anchor or rope system that does not operate as planned, including improper belay technique, improper clip-ins, or incorrect harness buckles or tie-ins.

- Any rock fall, falling object, or rolling-rock event that would result in significant injury in the event of a hit and in which the rock or object lands within 5 meters of a person.

- Anyone caught in an avalanche or any avalanche near miss.

\section{Wilderness travel}

- Any situation where someone becomes lost or disoriented, either traveling or in camp.

- Any fall from a horse.

- An unplanned or unanticipated swim while river crossing; simple stumbles caught without incident by the crossing party are excluded.

\section{Wildlife}

- A bear in camp, or any close or aggressive encounter with a bear, lion, wolf, crocodile, elephant, marine mammal, venomous snake, large ungulate, or person.

\section{River canoe/kayak/raft}

- Any broach or pin when the boat has folded or wrapped or is held against an obstacle by the current.

- When the structural integrity of a boat is compromised.

- If an individual swims, which would include swimming under an undercut or into a strainer.

These definitions allow us to rule-out routine incidents that we expect to happen, such as top-rope rock climbing falls, failure to roll a kayak for a beginning student, or a fall on the trail with no injury.

Table $4 \mathrm{a}$ and $\mathrm{b}$ lists the types of near-miss incidents and the contributing factors of near-miss incidents that have occurred and the activity at the time of the near miss. We use the same list of contributing factors for near misses as we do for injuries.

There were 325 near-miss incidents that involved students; 75 incidents involved only instructors, and 18 in- 
Table 4a. Near-miss profile: Type/contributing factor

\begin{tabular}{lcc}
\hline \multicolumn{1}{c}{ Near-miss type } & $\begin{array}{c}\text { No. of } \\
\text { near misses }\end{array}$ & $\begin{array}{c}\text { \% all } \\
\text { near miss }\end{array}$ \\
\hline Rock fall & 72 & 17.2 \\
Falls & 58 & 13.9 \\
Animal/insect/plant & 40 & 9.6 \\
Failed to follow instructions & 36 & 8.6 \\
Lost & 27 & 6.5 \\
Poor position & 23 & 5.5 \\
Exceeded ability & 16 & 3.8 \\
Loose rock & 15 & 3.6 \\
Other & 14 & 3.3 \\
Fast water & 13 & 3.1 \\
Judgment & 12 & 2.9 \\
Equipment & 10 & 2.4 \\
Communication & 10 & 2.4 \\
Supervision & 10 & 2.4 \\
Inexperience & 9 & 2.2 \\
Spilled hot water/stove fire & 9 & 2.2 \\
Weather & 8 & 1.9 \\
Technique & 7 & 1.7 \\
Haste & 5 & 1.2 \\
11 incidents at $<1 \%$ each & 24 & 5.7 \\
Total & 418 & 100 \\
& & \\
\hline
\end{tabular}

cidents involved both students and instructors. There were also 12 transportation-related near-miss incidents. These are not counted as field incidents and are not included in Table 4a and b, but they are very important incidents for us to monitor.

The near-miss profile is the only profile that has seen an increase in the incident rate (see Table 1). This is due to better understanding of the importance of near-miss incidents and to better reporting. Near-miss incidents are considered important predictors of future incidents. We strive to maintain an atmosphere where near misses can be reported and discussed among instructors and managers in an effort to learn from our experiences and better manage risk.

Rock fall was the leading type of near-miss incident. Rock fall is a known hazard in mountaineering ${ }^{3}$ and receives considerable attention in student and staff training and program risk-management practices. As one might expect, the majority $(62 \%)$ of rock-fall incidents occurred during rock climbing (43\%) and mountaineering (19\%) activities. Twenty-four percent of the rock fall near-miss incidents occurred while hiking through steep mountainous or canyon terrain. However, rock fall does not result in many injuries. There were 4 student injuries due to rock fall for this period.

As with injuries, falls are a leading contributing factor
Table $4 \mathbf{b}$. Near-miss profile: Activity at time of near miss

\begin{tabular}{lcc}
\hline \multicolumn{1}{c}{ Activity } & $\begin{array}{c}\text { No. of } \\
\text { near misses }\end{array}$ & $\begin{array}{c}\text { \% all } \\
\text { near misses }\end{array}$ \\
\hline Hiking with pack & 71 & 17.0 \\
Rock climbing & 65 & 15.6 \\
In camp & 47 & 11.2 \\
Canoeing & 44 & 10.5 \\
Mountaineering & 34 & 8.1 \\
Horse packing/riding & 24 & 5.7 \\
Sea kayaking & 18 & 4.3 \\
River kayaking & 16 & 3.8 \\
Glaciering & 14 & 3.3 \\
Cooking & 13 & 3.1 \\
River crossing & 13 & 3.1 \\
Sailing & 11 & 2.6 \\
Hiking without pack & 11 & 2.6 \\
Student expedition & 9 & 2.2 \\
River rafting & 6 & 1.4 \\
Caving & 5 & 1.2 \\
Swimming/wading & 4 & 1.0 \\
6 incidents at $<1 \%$ each & 13 & 3.1 \\
Total & 418 & 100 \\
& & \\
\hline
\end{tabular}

of near-miss incidents. Sixty percent of the falls occurred during hiking, horse riding, and while in camp, with $38 \%$ occurring during technical climbing and mountaineering.

\section{Nonmedical incident profile}

Nonmedical incidents occur when a student needs to leave a course early for reasons that are not medical. Table 5 lists the types of nonmedical incidents we experience. Motivational nonmedical incidents are the most prevalent, accounting for $55 \%$ of nonmedical incidents. Motivational incidents are voluntary withdrawals from NOLS and are influenced mainly by lack of desire to participate, but they also include personal is-

Table 5. Student nonmedical incident profile

\begin{tabular}{lrr}
\hline \multicolumn{1}{c}{ Nonmedical incident type } & No. & $\%$ \\
\hline Motivation & 155 & 54 \\
Verbal/physical behavior & 32 & 11 \\
Drugs/alcohol & 27 & 10 \\
Psychological history & 27 & 10 \\
Fitness/ability & 26 & 9 \\
Safety/judgment/poor performance & 15 & 5 \\
$\quad$ Total & 282 & 100 \\
\hline
\end{tabular}


sues, family illness, or death in the family. NOLS courses are physically and emotionally challenging, and it is understandable that some students may change their mind and wish to leave once the course has begun. Sixty-one percent of all motivational incidents occur earlier than 10 days into the course. This roughly corresponds to the first ration period of most courses and an opportunity for relatively easy egress from the course.

The behavioral categories of verbal and physical behavior and drugs and alcohol are significant and may present emotional or physical risks to other students or the instructors. We have recognized the negative impact of these behaviors on the student experience and have taken steps to address the situation. We have set clearer expectations for acceptable student behavior, and we provide training to field staff to identify, prevent, and intervene on these behaviors if and when they do occur.

The rate for nonmedical evacuations increased sharply for the period of 1995-1998, whereas the rate for 19992002 has dropped. We believe this reflects better understanding and recognition of nonmedical behaviors. Of the 279 nonmedical incidents, $19(6.8 \%)$ of these students went on to finish their course. Two hundred sixty $(2.1 \%)$ of all the students left NOLS early for nonmedical reasons.

\section{Evacuation profile}

Evacuations occur when students or instructors must leave the field before the end of the course. Table $6 \mathrm{a}$ presents the medical evacuation profile listing the type (injury or illness) of evacuation, the number of evacuations per type, and the percentage of evacuations per incident type. For example, 179 athletic injury evacuations were $59 \%$ of all athletic injuries. Table $6 \mathrm{~b}$ lists the reason for the injury or illness that lead to evacuation.

Medical evacuations generally indicate that the person's condition was such that he or she needed medical care or was no longer able to participate on the course because of the medical condition. The term evacuation does not indicate the urgency of medical condition. Most patients (evacuees) leave the field under their own power or are assisted by boats or horses. We average about 3 helicopter evacuations per year school wide. As a matter of policy, all medical evacuees are examined by a health care professional. On average, about 2 evacuees per year are hospitalized for at least 1 night.

Our medical evacuation rates (see Table 1) for 19992002 continue to show a downward trend and are $15 \%$ lower than the previous study period. The injury and illness rates have decreased roughly the same.

The most common types of evacuations are athletic and soft-tissue injuries. This should be expected because
Table 6a. Student medical evacuation profile: Evacuation type

\begin{tabular}{|c|c|c|}
\hline Medical evacuation type & $\begin{array}{c}\text { No. of } \\
\text { evacuations }\end{array}$ & $\begin{array}{c}\% \text { per } \\
\text { incident } \\
\text { type }\end{array}$ \\
\hline Athletic & 179 & 59 \\
\hline Soft tissue, all & 69 & 37 \\
\hline Burns & 7 & 23 \\
\hline Blisters & 13 & 59 \\
\hline Wound infections & 6 & 46 \\
\hline Stings & 1 & 6 \\
\hline Abdominal pain & 25 & 78 \\
\hline Other illness & 20 & 67 \\
\hline Flu symptoms & 20 & 38 \\
\hline Diarrhea & 18 & 20 \\
\hline Fracture & 18 & 82 \\
\hline Gender related* & 15 & 42 \\
\hline Dental & 14 & 74 \\
\hline Nausea & 14 & 50 \\
\hline Infection (illness) & 13 & 20 \\
\hline Respiratory symptoms & 11 & 50 \\
\hline Dislocation & 10 & 50 \\
\hline Head without loss of consciousness & 10 & 43 \\
\hline Acute mountain sickness & 10 & 53 \\
\hline Tick fever & 6 & 86 \\
\hline Asthma & 6 & 67 \\
\hline \multicolumn{3}{|l|}{ Urinary tract infection } \\
\hline ( 3 women and 2 men) & 5 & 17 \\
\hline Nonfreezing cold injury & 5 & 50 \\
\hline Cardiac & 4 & 67 \\
\hline Diabetes & 3 & 75 \\
\hline Seizure & 3 & 100 \\
\hline Other injury & 2 & 33 \\
\hline Allergy & 2 & 11 \\
\hline Fever & 2 & 100 \\
\hline Chest pain & 2 & 67 \\
\hline Head with loss of consciousness & 1 & 50 \\
\hline Hypothermia & 1 & 14 \\
\hline Total & 488 & $\ldots$ \\
\hline
\end{tabular}

*8 women and 7 men; dysmenorrhea, mittelschmerz, vaginitis, ectopic pregnancy, testicular torsion, epididymitis.

these are the most common medical conditions. In total, almost $46 \%$ of all medical incidents result in an evacuation $(51 \%$ of injuries and $38 \%$ of illnesses). However, 257 (53\%) medical evacuees received treatment and were able to rejoin and finish their course. Sixty-three percent of students returning to the field are semester participants, where it is logistically easier to rejoin. Two hundred thirty-one students, or $1.8 \%$ of all students, had to leave NOLS early for medical reasons.

When the nonmedical and medical profiles are combined, a total of 491 students (3.9\%) left NOLS early. 
Table 6b. Student medical evacuation profile: Reason for evacuation

\begin{tabular}{|c|c|c|}
\hline Reason for medical evacuation & $\begin{array}{c}\text { No. of } \\
\text { evacuations }\end{array}$ & $\begin{array}{c}\% \text { of } \\
\text { evacuations }\end{array}$ \\
\hline Unknown* & 118 & 24.2 \\
\hline Overuse & 103 & 21.1 \\
\hline Falls & 89 & 18.0 \\
\hline Previous history & 47 & 9.6 \\
\hline Animal/insect/plant & 21 & 4.3 \\
\hline Other & 15 & 3.1 \\
\hline Altitude & 12 & 2.5 \\
\hline Dental & 11 & 2.3 \\
\hline Hygiene & 7 & 1.4 \\
\hline Technique & 6 & 1.2 \\
\hline Spilled hot water & 6 & 1.2 \\
\hline Fatigue & 5 & 1.0 \\
\hline Inexperience & 5 & 1.0 \\
\hline Food or water & 5 & 1.0 \\
\hline Asthma & 4 & 0.8 \\
\hline Exceeded ability & 3 & 0.6 \\
\hline Failed to follow instructions & 3 & 0.6 \\
\hline Loose rock, not rock fall & 3 & 0.6 \\
\hline Fast water & 3 & 0.6 \\
\hline Equipment & 3 & 0.6 \\
\hline Carelessness & 2 & 0.4 \\
\hline Weather & 2 & 0.4 \\
\hline Unsafe speed & 2 & 0.4 \\
\hline Lack of fitness & 2 & 0.4 \\
\hline Visibility & 2 & 0.4 \\
\hline Rock fall & 1 & 0.4 \\
\hline Misbehavior & 1 & 0.2 \\
\hline Haste & 1 & 0.2 \\
\hline Games & 1 & 0.2 \\
\hline Poor position & 1 & 0.2 \\
\hline Judgment & 1 & 0.2 \\
\hline Medications & 1 & 0.2 \\
\hline Stove fire & 1 & 0.2 \\
\hline Wet slippery terrain & 1 & 0.2 \\
\hline Total & 489 & 100 \\
\hline
\end{tabular}

*12 injuries and 106 illnesses.

In other words, $96.1 \%$ of NOLS students completed their course during this 4-year period.

\section{Fatalities}

There was 1 fatality from 1999 to 2002. A student on a 30-day Alaska mountaineering course disappeared when he camped on a glacier. He was last seen going for water at a short distance from but out of sight of camp. Because of the ice and rock on the surface of the glacier, there was no sign of what occurred. After thorough investigation by law enforcement, NOLS, and a private inquiry, he was presumed to have died by falling into a moulin (a vertical shaft formed in glacial ice by meltwater) that was near where he disappeared. The fatality rate for this period is 0.002 per 1000 program days. From 1984 to 1998 , there were 3 fatalities with a fatality rate of 0.002 per 1000 program days. At this rate, for every 500000 -program days there is 1 fatality. On the basis of the average annual program days during the period of 1999-2002 (157 734 program days), there could be 1 fatality on a NOLS course for every 3.17 years.

Our courses have many inherent risks which are managed well by professional and highly trained field and management staff. Circumstances may arise, however, which result in loss of life.

\section{Comparative analysis}

Table 7 lists injury and fatality statistics for various other activities. Direct comparison of these data and NOLS data is not possible because of the differences in data collection and how the risk exposure is expressed. When making comparisons with larger populations, extrapolations of the NOLS data become skewed. However, the available data about other activities or other causes of injury or death may provide some perspective when considering the risk of injury or death from participation on a NOLS course.

\section{Conclusions}

NOLS incident rates are continuing to decline except in the category of near-miss incidents. The number of injuries, specifically the number of athletic injuries, have continued to decline. The rate of all illnesses declined slightly, but the rate of gastrointestinal symptoms rose slightly. The number of medical evacuations declined by $15 \%$ from the previous period. The rates for both illness evacuations and injury evacuations declined. These improvements in our statistics reflect the improvement, dedication, and focus of staff and management. We care deeply about the health and safety of students and staff, as shown by how we keep and use these statistics to evaluate and adjust our program and practices when necessary. The statistics show our ability to care for the health and safety of our students as we travel through mountains, deserts, oceans, and rivers.

Both the number and the rate of near-miss incidents increased. We believe this is a result of better reporting, which includes an improved understanding of what constitutes a near miss and, for the staff, a better understanding of the value of reporting these incidents to promote organizational learning. Our efforts at creating an at- 
Table 7. Annual injury and fatality statistics for other activities*

\begin{tabular}{lccc}
\hline \multicolumn{1}{c}{ Activity } & Injuries & Deaths & Rates \\
\hline Mountain climbing; national; 19994 & 3104 & NA & NA \\
Bicycling; national; 19994 & 595679 & 809 & NA \\
Football; national; 19994 & 372380 & $6 / 12 \dagger$ & NA \\
Soccer; national; 19994 & 175303 & NA & NA \\
Motor vehicle; 1998; age 15-244 & & 10026 & 26.9/100 000 population \\
Motor vehicle; 1998; age 25-344 & & 7132 & $18.4 / 100$ 000 population \\
Home unintentional injury deaths; 2000; age 15-244 & & 1200 & 3.0100000 population of age group \\
Home unintentional injury deaths; 2000; age 25-444 & & 6900 & 8.5100000 population of age group \\
Skiing/snowboarding; national; 1999-20005 & & 12 & NA \\
Colorado climbing/hiking average annual 1996-19986 & & 12 & NA \\
Colorado snow skiing average annual 1996-19986 & & 10 & NA \\
Colorado bicycling average annual 1996-19986 & & \\
\hline
\end{tabular}

*NA indicates not available.

$\uparrow 6$ direct fatalities, 12 indirect fatalities from exertion or complications caused by playing football.

mosphere that values honesty in reporting over punitive action has improved risk management at NOLS.

The rate of nonmedical incidents held steady (slight decline), whereas the actual number of such incidents increased. NOLS has devoted significant resources, including staff training time, staff time for curriculum development, and tools created for staff to be better able to recognize behavioral problems among students and take appropriate actions. The importance of this effort is directly related to the core values of NOLS, which include community and development of leadership skills that rely on good expedition behavior, teamwork among students, and creation of an optimum learning environment. Motivation continues to be our leading category of nonmedical incident in spite of our efforts to accurately portray the demands of a NOLS course.

The commitment that NOLS has placed on risk management has resulted in better understanding of the risks of a NOLS course, excellent field- and risk-management practices, and a high student success rate $(96.1 \%$ of students complete their course). NOLS will continue to be committed to risk management with the main objective of preventing fatalities and serious injuries and illnesses while meeting our educational objectives. NOLS is focused on providing excellent supervision and instruction to our students, honest field incident reporting from our instructors, and a climate where we are open to discussing new ideas and methods. As this paper has shown, our efforts at collecting incident data provide a useful measurement from which we can gauge our risk-management performance.

\section{References}

1. Webster's Collegiate Dictionary. 10th ed. Springfield, MA: Merriam-Webster; 1998.

2. Gentile DA, Morris JA, Schimelpfenig T, Bass SM, Auerbach PS. Wilderness injuries and illness. Ann Emerg Med. 1992;21:853-861.

3. Williamson J. Accidents in North American Mountaineering. Golden, CO: The American Alpine Club; 2001.

4. Injury Facts 2001. Itasca, IL: National Safety Council; 2001.

5. National Ski Areas Association. Ski and snowboard safety. Facts about skiing/snowboarding safety. Available at: http:// www.nsaa.org/nsaa2002/_safety.asp. Accessed November 15, 2001.

6. Colorado Department of Public Health and Environment. Recreational fatalities in Colorado, 1996-1998, July 2000. Available at: http://www.cdphe.state.co.us/hs/. Accessed June 27, 2003. 